\title{
Review
}

\section{Biochemical mechanisms of HIV induced T cell apoptosis}

\author{
N Selliah ${ }^{1}$ and TH Finkel $\left.\right|^{*, 1,2}$ \\ 1 Division of Rheumatology, The Children's Hospital of Philadelphia, 3516 Civic \\ Center Blvd., Philadelphia, PA 19104, USA \\ 2 Department of Pediatrics, University of Pennsylvania, Philadelphia, PA 19104, \\ USA \\ * Corresponding author: TH Finkel, Division of Rheumatology, The Children's \\ Hospital of Philadelphia, 3516 Civic Center Blvd, Philadelphia, PA 19104, USA \\ Tel: +1 215590 1870; Fax: +1 215590 1258; \\ E-mail: FINKELT@EMAIL.CHOP.EDU
}

Received 30.10.00; accepted 4.12.00

Edited by JM Hardwick

Keywords: apoptosis; HIV; immunity

Abbreviations: TNF, tumor necrosis factor; PBL, peripheral blood lymphocytes; FAK, focal adhesion kinase; HIV, human immunodeficiency virus

\section{Introduction}

Acute HIV infection is often accompanied by a flu-like illness and is associated with a high-titer viremia. This viremia is quickly controlled by the immune response, mediated predominantly by cytotoxic $\mathrm{CD} 8^{+} \mathrm{T}$ lymphocytes $(\mathrm{CTL})$, and, to some extent, by anti-HIV antibodies. ${ }^{1,2}$ In most individuals, plasma viral load is maintained at low levels for years and the individual remains asymptomatic. However, during this 'clinical latency', plasma viral RNA is detectable and viral turnover is brisk, with large numbers of viruses produced and destroyed each day. ${ }^{3}$ For reasons that are not yet clear, a break in this control leads to a significant decline in the number of $\mathrm{CD} 4^{+} \mathrm{T}$ cells, and a rapid increase in viral load. It is after this break in immune control that the clinical symptoms of AIDS appear. ${ }^{4}$

Over the past several years, tremendous progress has been made in our understanding of the biology of HIV infection and the mechanisms of HIV replication and its control. However, the biochemical mechanism(s) of HIVinduced T cell death, including death of uninfected $\mathrm{CD} 4^{+}$and $\mathrm{CD}^{+} \mathrm{T}$ cells, are not well defined. Here, we discuss the role of viral and cellular proteins in HIV-infected and -uninfected T cell death. We also discuss mechanisms by which HIV may actually protect infected $T$ cells from apoptosis. Current therapy to enhance immune system function and to decrease bystander $\mathrm{T}$ cell death (thereby, increasing $\mathrm{CD}^{+} \mathrm{T}$ cell number) in HIV infected individuals will also be discussed.

\section{Apoptosis of HIV infected T cells}

In HIV infected individuals, viral load is a good predictor of disease progression: the higher the viral load, the faster the disease progression. ${ }^{5,6}$ Some studies have also shown a correlation between the extent of apoptosis and disease progression, ${ }^{7,8}$ suggesting that, in vivo, HIV kills the $\mathrm{CD}^{+} \mathrm{T}$ cell that it infects. These observations argue that the virus is responsible for the depletion of $\mathrm{CD} 4^{+} \mathrm{T}$ cells. Not addressed by these studies, however, are the mechanisms by which HIV depletes its host of $\mathrm{CD} 4^{+} \mathrm{T}$ cells. In this section of the review, we will focus on mechanisms of T cell killing by HIV, although recent data suggest that failure of $T$ cell regeneration also plays an important role in $\mathrm{CD}^{+} \mathrm{T}$ cell loss in HIV disease..$^{9,10}$ In later sections of this review, we will discuss an alternate thesis, based on data suggesting that HIV and SIV have evolved mechanisms of blocking or delaying the cellular suicide program. Tables 1-3 summarize much of the published data on cell death in HIV disease. Interestingly, several HIV gene products have been reported to both induce and inhibit apoptosis, a recurring theme in the apoptosis literature.

One major pathway of $\mathrm{T}$ cell apoptosis is mediated through the tumor necrosis factor (TNF) family of receptors. The Fas receptor, in particular, has been extensively studied in recent years. Ligation of Fas by Fas ligand (FasL), present on the same or on a neighboring cell, can induce apoptosis. ${ }^{11-13}$ Data are controversial regarding involvement of Fas in HIV-induced T cell death (reviewed in $^{14,15}$ ).

Peripheral blood lymphocytes (PBL) from $\mathrm{HIV}^{+}$individuals have higher Fas expression, ${ }^{16}$ and the proportion of Fas-expressing $T$ cells increases with disease progression. ${ }^{17} \mathrm{CD}^{+}$and $\mathrm{CD}^{+}$T cells from HIV infected individuals are more susceptible to death induced by Fas ligation. ${ }^{16,18}$ In vitro studies from our lab show that HIV infected $T$ cells become more susceptible to Fas induced apoptosis. ${ }^{19}$ In this study, we showed that the increase in sensitivity of HIV infected cells to Fas killing mapped to the HIV gene product, Vpu. Another viral protein, Tat, has been shown to sensitize T cells to TCR- and CD4-induced apoptosis by upregulation of FasL expression, ${ }^{20}$ and to increase the sensitivity to Fas mediated apoptosis by upregulation of caspase-8. ${ }^{21}$ Furthermore, Nef has been shown to increase surface expression of both Fas and FasL, and Nef's ability to interact with cellular kinases is required for this increased expression and for apoptosis. ${ }^{22}$

Viruses are notorious for interfering in 'internal matters' of the host cell in ways which may be beneficial to the virus, but which may ultimately induce cell death. Tat, one of the early HIV gene products, has been shown to induce reactive oxygen intermediates, caspase activation, and activation of NF- $\kappa \mathrm{B}, \mathrm{AP}-1$, and JNK, in a p56 $6^{\mathrm{lck}}$ dependent manner. ${ }^{23}$ These data suggest that binding of HIV to CD4 activates $\mathrm{p} 56^{\mathrm{lck}}$ and other downstream signaling events, which prepares the cell for HIV production (for example, by $\mathrm{NF}-\kappa \mathrm{B}$ activation), but which also induces apoptosis (for example, by caspase activation). 
Table 1 HIV gene products implicated in the control of cell death. Means by which HIV may cause apoptosis or necrosis in highly infected cells

\begin{tabular}{|c|c|c|}
\hline $\begin{array}{l}\text { HIV gene } \\
\text { product }\end{array}$ & Alteration of cellular function & $\begin{array}{l}\text { Refer- } \\
\text { ence }\end{array}$ \\
\hline \multirow[t]{4}{*}{ Vpr } & Cell cycle arrest in G2 & 33,106 \\
\hline & Cell cycle arrest in $\mathrm{G} 1$ & 37 \\
\hline & Caspase activation & 38 \\
\hline & $\begin{array}{l}\text { Dissipation of the mitochondrial } \\
\text { transmembrane potential }\end{array}$ & 24 \\
\hline Vpu & $\begin{array}{l}\text { Increased susceptibility to Fas-induced } \\
\text { death }\end{array}$ & 19 \\
\hline \multirow[t]{4}{*}{ Tat } & $\begin{array}{l}\text { Increased activity of cyclin A-dependent } \\
\text { kinases }\end{array}$ & 88 \\
\hline & Increased Fas and Fas-L expression & 20,66 \\
\hline & Increased caspase- 8 activity & 21 \\
\hline & Decreased Bcl-2 activity & 28 \\
\hline Nef & Upregulation of Fas and FasL & 22 \\
\hline \multirow{7}{*}{$\begin{array}{l}\text { Env (gp120 } \\
\text { /gp160) }\end{array}$} & Increased fas expression & 107 \\
\hline & Induction of CD4-Lck interaction & 108 \\
\hline & Increased membrane permeability & 109 \\
\hline & Syncytia formation & 110 \\
\hline & $\begin{array}{l}\text { Formation of intracellular CD4-gp160 } \\
\text { complexes }\end{array}$ & 111 \\
\hline & Activation of AP-1 & 112 \\
\hline & Activation of Lck and Raf-1 & 113 \\
\hline HIV protease & Cleavage of $\mathrm{Bcl}-2$ & 29,30 \\
\hline $\begin{array}{l}\text { Unintegrated } \\
\text { viral DNA }\end{array}$ & Induction of cytolysis & $\begin{array}{l}\text { reviewed } \\
\text { in } 114\end{array}$ \\
\hline Many & $\begin{array}{l}\text { Targeting for cytotoxic T lymphocyte- } \\
\text { mediated killing }\end{array}$ & 115 \\
\hline Many & $\begin{array}{l}\text { Targeting for lymphokine-activated } \\
\text { killers }\end{array}$ & 116 \\
\hline Many & $\begin{array}{l}\text { Targeting for antibody-dependent } \\
\text { cellular cytotoxicity }\end{array}$ & 116 \\
\hline Many & $\begin{array}{l}\text { Targeting for complement-mediated } \\
\text { lysis }\end{array}$ & 117 \\
\hline Unknown & Induction of necrosis & 118 \\
\hline Unknown & Activation of ICE-like proteases & 119 \\
\hline Unknown & $\begin{array}{l}\text { Increased expression of Fas-L on } \\
\text { macrophages }\end{array}$ & 120 \\
\hline
\end{tabular}

One of the accessory proteins of HIV-1, Vpr, has been shown to induce $T$ cell apoptosis. Synthetic $\mathrm{Vpr}$ added to intact $T$ cells causes a rapid dissipation of the mitochondrial transmembrane potential, as well as the release of cytochrome $c$ and cellular apoptosis. ${ }^{24}$ These data support evidence of Macho et al. showing that $\mathrm{T}$ cells from $\mathrm{HIV}^{+}$ individuals have dysfunctional mitochondria, reduced mitochondrial transmembrane potential, and increased generation of superoxide anion. ${ }^{25}$ The dissipation of the mitochondrial transmembrane potential and the apoptosis induced by $\mathrm{Vpr}$ can be inhibited by the cellular antiapoptotic protein, $\mathrm{Bcl}-2 .{ }^{24}$ But HIV has also been shown to down-regulate $\mathrm{Bcl}-2$ by a number of different mechanisms. Levels of Bcl-2 are significantly lower in PBL from HIV infected individuals with high levels of viral replication. ${ }^{26}$ Spontaneous apoptosis of $\mathrm{CD} 4^{+}$and $\mathrm{CD} 8^{+} \mathrm{T}$ cells from HIV infected individuals correlates with downregulation of $\mathrm{Bcl}-2$ and is partially prevented by anti-retroviral therapy or by IL$2 .^{27}$ The HIV-1 transcriptional regulatory protein, Tat, has been shown to decrease $\mathrm{Bcl}-2$ expression. ${ }^{28}$ HIV protease has been shown to cleave $\mathrm{Bcl}-2$ and this is correlated with induction of apoptosis. ${ }^{29,30}$ Another mechanism of HIV induced downregulation of Bcl-2 may be via inhibition of the JAK3 (Janus Family kinase)/STAT5 (Signal Transducers
Table 2 HIV gene products implicated in the control of cell death. Means by which HIV may induce death in uninfected bystander cells

\begin{tabular}{|c|c|c|}
\hline $\begin{array}{l}\text { HIV gene } \\
\text { product }\end{array}$ & Alteration of cellular function & $\begin{array}{l}\text { Refer- } \\
\text { ence }\end{array}$ \\
\hline Tat & Increased Fas-L expression & 20,66 \\
\hline \multirow{11}{*}{$\begin{array}{l}\text { Env (gp120 } \\
\text { /gp160) }\end{array}$} & Induction of 'mitotic catastrophe' & 106,110 \\
\hline & Increased Fas expression & 107 \\
\hline & Induction of cytolysis & $45,46,121$ \\
\hline & $\begin{array}{l}\text { Induction of apoptosis of preactivated } \\
\text { cells }\end{array}$ & 122 \\
\hline & Priming for activation-induced apoptosis & 123,124 \\
\hline & Increased membrane permeability & 109 \\
\hline & Activation of AP-1 & 112 \\
\hline & Activation of Lck and Raf-1 & 113 \\
\hline & $\begin{array}{l}\text { Activation of caspase- } 3 \text { and caspase- } 6 \\
\text { and induced cleavage of Focal } \\
\text { adhesion kinase }\end{array}$ & 47,50 \\
\hline & Decreased Bcl-2 expression & 56 \\
\hline & $\begin{array}{l}\text { Decreased JAK3 expression and } \\
\text { activation }\end{array}$ & 58 \\
\hline Vpr & Cell cycle arrest in G2 & 33 \\
\hline Many & $\begin{array}{l}\text { Cytokine-induced cell death or } \\
\text { cytokine withdrawal }\end{array}$ & $\begin{array}{l}\text { reviewed } \\
\text { in }{ }^{114}\end{array}$ \\
\hline Many & Exhaustive activation & 125 \\
\hline Unknown & Telomere shortening in $\mathrm{CD}^{+} \mathrm{T}$ cells & 126,127 \\
\hline Unknown & Activation of ICE-like proteases & 119 \\
\hline Unknown & $\begin{array}{l}\text { Increased susceptibility to Fas-induced } \\
\text { cell death }\end{array}$ & $16,18,128$ \\
\hline Unknown & $\begin{array}{l}\text { Increased expression of Fas-L on } \\
\text { macrophages }\end{array}$ & 120 \\
\hline
\end{tabular}

Table 3 HIV gene products implicated in the control of cell death. Means by which HIV may prevent or delay apoptosis in infected cells

\begin{tabular}{llc}
\hline $\begin{array}{l}\text { HIV gene } \\
\text { product }\end{array}$ & Alteration of cellular function & $\begin{array}{c}\text { Refer- } \\
\text { ence }\end{array}$ \\
\hline Tat & $\begin{array}{l}\text { Inhibition of apoptosis } \\
\text { Inhibition of antigen-induced proliferation }\end{array}$ & $129-131$ \\
& Decreased MHC class I expression & 132 \\
& Increased Bcl-2 expression & 133 \\
& Decreased p53 expression & 134 \\
Nef & Increased endocytosis of CD4 & 88 \\
& Inhibition of Lck activation & 76 \\
& Downregulation of TCR & $81,83,135$ \\
& Increased FasL expression & 83,84 \\
& Binding of p53, Hck, pp44 MAPK/ERK1 & 85 \\
& Decreased expression of IL-2R $\alpha$ chain & 83,136 \\
& Inhibition of proliferation in response to IL-2 & 83 \\
Vpu & Decreased MHC class I surface expression & 86,133 \\
Vpr & Degradation of CD4 & 77,78 \\
& Inhibition of activation of pp34cdc2-cyclin B & 34,35, \\
& & 137,138 \\
Env (gp120 & Inhibition of surface expression of CD4 by & 90 \\
/gp160) & binding to CD4 in the ER & 77 \\
Capsid & Binding to cyclophilins A and B & 140 \\
\hline
\end{tabular}

and Activators of Transcription) activation pathway, which is necessary for growth factor-dependent $T$ cell proliferation and survival. ${ }^{31}$ Interestingly, our data show that the HIV-1 clonal isolate, NL4-3, inhibits the JAK3/STAT5 activation pathway (Selliah and Finkel, manuscript submitted). The JAK3/STAT5 signaling pathway has been shown to upregulate anti-apoptotic proteins, such as $\mathrm{Bcl}-2$ and $\mathrm{Bcl}-$ $\mathrm{XL} .{ }^{31,32}$ These data suggest that HIV mediated inhibition of 
anti-apoptotic mechanisms in host cells may further enhance spontaneous apoptosis or the apoptosis induced by $\mathrm{Vpr}$ or other viral proteins.

Another function of $\mathrm{Vpr}$ is cell cycle arrest. Relevant to our subsequent discussion of HIV-induced death of bystander cells, $\mathrm{Vpr}$ induces cell cycle arrest in both infected and uninfected cells. ${ }^{33} \mathrm{Vpr}$ arrests cells in the G2 phase of the cell cycle by inhibiting activation of p34 ${ }^{\mathrm{cdc} 2}$. cyclin B. ${ }^{34,35}$ The activity of p34 ${ }^{\text {cdc2 }}$-cyclin B is critical for entry into mitosis and requires removal of the phosphate residues on $\mathrm{p} 34^{\mathrm{cdc} 2}$ that inhibit kinase function. ${ }^{35} \mathrm{In} \mathrm{Vpr}$ expressing cells, phosphatase cdc25C, which removes phosphate from $\mathrm{p} 34^{\mathrm{cdc} 2}$, is in an inactive form, suggesting that the target for $\mathrm{Vpr}$ is either cdc25C or an upstream regulator of cdc25C. Recently, Hrimech et al. reported that Vpr mediates G2 arrest by forming a complex with protein phosphatase 2A (PP2A), an upstream regulator of cdc25, and enhances the nuclear import of PP2A. ${ }^{36}$ In the nucleus, Vpr-PP2A complex binds and dephosphorylates cdc25, rendering it inactive.

G2 arrest by Vpr has been characterized as beneficial to HIV, resulting in production of more virions, although the cellular response to this arrest is suicide. ${ }^{34,35}$ Interestingly, Nishizawa et al. reported recently that a carboxy-terminal truncation of Vpr induces apoptosis via G1 arrest of the cell cycle. ${ }^{37}$ Another study showed that apoptosis induced by $\mathrm{Vpr}$ requires caspase activation. ${ }^{38}$ These data show that $\mathrm{Vpr}$ may regulate cellular function, including the cell cycle, and induce apoptosis via multiple and complex pathways. Our recent data suggest that another HIV-1 accessory protein, Vif, contributes to the aberrant cell cycle regulation and apoptosis in HIV infected T cells (Casella et al., manuscript submitted). Collectively, these data argue that HIV interferes with cellular functions for the benefit of replication and production of more virus, but that the cellular response to this interference is activation of apoptotic signaling pathways (Figure 1).

\section{Apoptosis of uninfected T cells: bystander cell death}

Despite the high viral burden and turnover throughout the course of HIV infection, only a small fraction $(<0.1 \%)$ of $\mathrm{CD}^{+} \mathrm{T}$ cells are productively infected. ${ }^{39}$ Notably, the number of apoptotic CD4 ${ }^{+} \mathrm{T}$ cells from the peripheral blood of HIV-infected individuals is greater than the number of infected cells, suggesting that uninfected cells die by apoptosis. ${ }^{40}$ Apoptosis is seen in PBL of HIV infected individuals in both the $\mathrm{CD}^{+}$and $\mathrm{CD}^{+} \mathrm{T}$ cell subsets. ${ }^{7,8,40,41}$ A study of a large cohort of HIV-infected individuals at various stages of disease showed that the degree of apoptosis was significantly higher in $\mathrm{CD}^{+}, \mathrm{CD}^{+}$, and $\mathrm{B}$ cells, compared to uninfected individuals, and was correlated with disease progression. ${ }^{7}$ This study showed a low level of apoptosis in long-term non-progressors and a high level of apoptosis in rapid progressors. In the lymph nodes, the major site of viral replication, ${ }^{4,39}$ we have shown that apoptosis is increased in the lymph nodes of HIVinfected children, adults and SIV-infected macaques, when compared to lymph nodes from uninfected controls. ${ }^{42,43}$

\section{Death of Infected Cells}

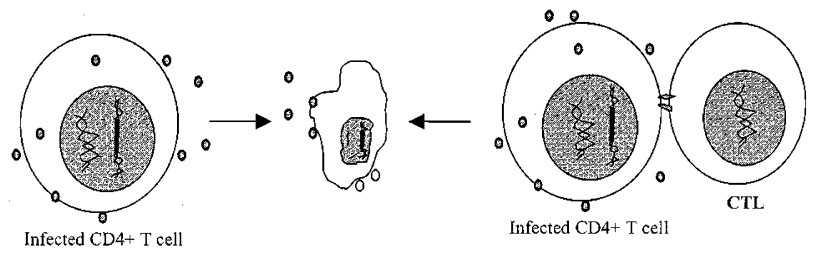

Mechanisms due to: HIV-induced cellular responses:

- Env binding to CD4 and CXCR4 or CCR5 induces caspase-3 activity.

- Tat upregulates Fas and Fas-L, increasing caspase-8 activity. Tat decreases Bcl-2 expression.

- Nef upregulates Fas and Fas-L.

- Vpu increases susceptibility to Fas-induced death.

- Vpr causes apoptosis after G2 arrest and dissipation of the mitochondrial transmembrane potential.

- Vif triggers cell cycle alterations which may lead to apoptosis.

- HIV protease cleaves Bcl-2.

\section{Host responses:}

- CTL killing

- Antibody dependent cellular cytotoxicity

Figure 1

Intriguingly, productively infected cells were only rarely apoptotic and apoptotic cells were only rarely productively infected. ${ }^{43}$ These data have been corroborated by Haase and coworkers in subsequent in situ analyses of apoptosis and infection ${ }^{44}$ (and personal communication). In addition, numbers of apoptotic cells in lymphoid tissue exceeded the numbers of productively infected cells, suggesting the occurrence of bystander cell death. ${ }^{40}$

The best-studied mechanism of bystander cell death in HIV infection is mediated by the binding of envelope glycoprotein (Env) to its cellular receptors (CD4 and a chemokine coreceptor), prior to viral fusion and entry. Apoptosis occurs in the absence of viral replication when infected and uninfected cells are cultured together. ${ }^{45,46}$ These data suggest that viral proteins interact with uninfected cells and induce an apoptotic signal. The binding of HIV-1 Env to CD4 and CXCR4 (the chemokine receptor utilized by $\mathrm{T}$ cell line-tropic HIV) or CCR5 (the chemokine receptor utilized by macrophage-tropic HIV) has been shown to induce apoptosis in primary $\mathrm{T}$ lymphocytes. ${ }^{47}$ Env exerts an inhibitory effect when cells are in the G0/G1 phase of the cell cycle. ${ }^{48}$ Thus, naïve $T$ cells (CD45RA cells) may be the most affected by Env mediated negative signaling. Interestingly, binding of HIV virions to CD45RA cells decreased mitogenic responses and induced activation-induced cell death (AICD), while memory $T$ cells 
(CD45RO cells) were less affected. ${ }^{49}$ Furthermore, cell cycle arrest at the $\mathrm{G} 1 / \mathrm{S}$ restriction point was seen only in CD45RA cells following binding of HIV virions.

Binding of Env to CD4 and to a coreceptor activated caspase-3 and caspase-6, and induced cleavage of focal adhesion kinase (FAK). ${ }^{47,50}$ Cleavage of FAK by caspase-3 and caspase- 6 leads to the disassembly of focal adhesion complexes and programmed cell death. ${ }^{51,52}$ It appears that while CXCR4 induced apoptosis is dependent upon caspase- 3 activation, it is insensitive to pertussis toxin and does not involve the activation of the p38MAPK or JNK ${ }^{50}$ Activation of caspase- 3 and caspase- 6 was induced by HIV-1 macrophage tropic Env in PBL from a CCR5 $\Delta 32$ donor (which have a non-functional coreceptor, due to a CCR5 deletion), suggesting that CD4 receptor engagement is sufficient to provide the stimulus for apoptosis. ${ }^{47}$ Caspases have been implicated in HIV-mediated apoptosis $^{53}$ and patients with progressive HIV disease demonstrate increased caspase-3 activity. ${ }^{54}$ Caspase- 3 has been shown to mediate cleavage of $\mathrm{Bcl}-2$ and promotes apoptosis. ${ }^{55}$ Interestingly, it has been reported that CD4 ligation decreases $\mathrm{Bcl}-2$ expression and induces apoptosis. ${ }^{56} \mathrm{Bcl}-2$ downregulation was observed in cultured $\mathrm{CD} 4^{+}$ $\mathrm{T}$ cells, $\mathrm{CD}^{+} \mathrm{T}$ cells and $\mathrm{B}$ cells from $\mathrm{HIV}^{+}$individuals. ${ }^{57}$ Thus, multiple signaling pathways appear to contribute to the apoptosis induced by ligation of the CD4 receptor.

Recently, we have shown that increases in JAK3 expression and JAK3 activation induced by antigen receptor ligation are inhibited by prior CD4 ligation by HIV gp120 or anti-CD4 mAb. ${ }^{58}$ The JAK3/STAT5 signaling pathway has been shown to play a major role in the development, proliferation, and survival of T cells ${ }^{59-61}$ (and reviewed $\mathrm{in}^{62,63}$ ). In vivo evidence for inhibition of the JAKSTAT pathway in HIV disease comes from data of Pericle et al. ${ }^{64}$ The authors observed a selective reduction of STAT5B expression in HIV infected PBMC and reduced expression of STAT1 $\alpha$, STAT5A and STAT5B in T cells from HIV seropositive individuals. These data argue that $T$ cell dysfunction and apoptosis in HIV disease may be due, in part, to aberrant regulation of the JAK3/STAT5 signaling pathway.

HIV-1 Tat protein has been shown to induce cell death by apoptosis in a T cell line and in cultured peripheral blood mononuclear cells from uninfected controls. ${ }^{65}$ This Tatinduced apoptosis was inhibitable by growth factors and was associated with enhanced activation of cyclindependent kinases. Tat is secreted from infected cells ${ }^{66}$ and may upregulate FasL on uninfected cells. ${ }^{20}$ These cells could then either kill themselves by binding Fas expressed on the same cell or kill another cell that has upregulated Fas. In addition, McCloskey et al. reported that addition of exogenous Tat induced apoptosis in Jurkat cells. ${ }^{67}$ Finally, it has been suggested that Tat binds to cell surface molecules, possibly to CD26 and the integrin, $\alpha_{5} \beta_{1}$, both of which transduce apoptotic signals. ${ }^{68-70}$

One mechanism of $\mathrm{CD}^{+} \mathrm{T}$ cell death in HIV disease, as reported by Herbein et al., is dependent upon macrophages. ${ }^{71}$ These authors showed that ligation of CXCR4 increased membrane bound TNF on macrophages and TNFRII on $\mathrm{CD}^{+} \mathrm{T}$ cells. The interaction between TNF and
TNFRII induced death of the $\mathrm{CD}^{+} \mathrm{T}$ cells. As discussed above, secreted Tat could also induce apoptosis of $\mathrm{CD} 8^{+} \mathrm{T}$ cells. Thus, as described previously for $\mathrm{CD}^{+} \mathrm{T}$ cells, there are multiple mechanisms of $\mathrm{CD}^{+} \mathrm{T}$ cell death in HIV disease (Figure 2).

\section{Inhibition of apoptosis by HIV}

HIV may kill the CD4 ${ }^{+} \mathrm{T}$ cell that it infects in vivo (as discussed above). However, emerging data suggest that HIV and SIV have evolved mechanisms of blocking or delaying the cellular suicide program. As has been described for many other viral infections, ${ }^{72}$ it may be beneficial for HIV to inhibit cellular apoptosis, at least until high levels of progeny virus are produced. As discussed below, several HIV-1 gene products have been shown to have anti-apoptotic activity, at least in vitro, and expression of known anti-apoptotic genes (i.e. E1B $19 \mathrm{~K}$ or a caspase inhibitor, N-benzyloxycarbonyl-Val-AlaAsp-fluoromethylketone [Z-VAD-fmk]) in HIV-1 infected cell lines increases virus production. ${ }^{73,74}$ In fact, recent studies demonstrating the persistence of latent or low level HIV-1 infection in vivo, in the face of intense anti-retroviral therapy, ${ }^{75}$ argue that not all infected cells die.

A first line of defense for HIV against cellular apoptosis would be to reduce the levels of surface CD4, to prevent infection by new viruses ('super-infection interference'), and to inhibit binding and negative signaling by soluble or cellular gp120. At least three HIV-encoded proteins, Nef, Env, and Vpu, contribute to the down-regulation of CD4. Nef, a protein predominantly expressed early in infection, reduces the level of CD4 on the surface by inducing endocytosis. ${ }^{76}$ Env binds CD4 in the endoplasmic reticulum

\section{Bystander Cell Death}
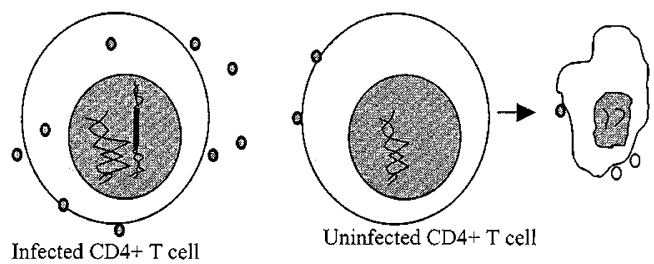

Mechanisms:

- Soluble Tat can cause apoptosis of uninfected T-cells.

- Macrophages in infected cultures can cause the death of uninfected $\mathrm{CD}^{+}{ }^{+} \mathrm{T}$-cells.

- Vpr causes G2 arrest and apoptosis in bystander cells. Vpr may cause dissipation of the mitochondrial transmembrane potential in bystander cells, leading to death.

- Env-CD4 and CXCR4 or CCR5 interactions on bystander cells by defective virus or soluble gp120 leads to apoptosis.

Figure 2 
and thereby inhibits expression. ${ }^{77} \mathrm{Vpu}$, a protein expressed late in the viral life cycle, facilitates the degradation of CD4 by binding to a cellular factor, $\mathrm{h}-\beta \operatorname{TrCP}$, and targets CD4 for ubiquitin-mediated proteolysis. ${ }^{78,79}$

Nef has been shown to inhibit $T$ cell activation pathways by interaction with cellular signal transduction proteins [reviewed in ${ }^{80}$ ]. Nef binds to p56 $6^{\text {lck }}$ and inhibits its kinase activity. ${ }^{81}$ In addition, recent data show that Nef binds to TCR $\xi$-chain, resulting in downmodulation from the cell surface. $^{82}$ Both $\mathrm{p} 56^{\mathrm{lck}}$ and TCR $\xi$-chain are required for downstream events of $\mathrm{T}$ cell signal transduction. Thus, the interaction of Nef with p56 ${ }^{\text {lck }}$ and TCR $\xi$-chain may prevent AICD of HIV infected cells. ${ }^{83,84}$ In related studies, $\mathrm{Xu}$ et al. have shown that Nef binds to TCR $\xi$-chain and increases FasL expression. ${ }^{85}$ The authors suggest that Nef binds to TCR, initiating signaling and upregulation of FasL, without the requirement for antigen engagement. Nef has also been shown to reduce $\mathrm{MHC}$ class I on the surface by inducing endocytosis. $^{86}$ Downregulation of MHC class I and upregulation of FasL by HIV-1 and SIV Nef may protect infected cells from CTL mediated lysis. ${ }^{86,87}$

Nef has also been reported to bind to $p 53^{83}$ and Tat decreases transcription of $p 53 .^{88}$ Downregulation of $p 53$ and inactivation of $\mathrm{p} 53$ regulatory functions may promote cell cycle progression, inhibit apoptosis, and produce cell transformation. Recently, Clark et al. reported that HIV infected $\mathrm{T}$ cells bypass the G1/S checkpoint by inhibiting p2 $1^{\text {Waf1 }}$, a known cyclin dependent kinase inhibitor. ${ }^{89}$ This inhibition is mediated by the binding of p53 by Tat, and sequestration of its transactivation activity. The authors postulate that this loss of the G1/S checkpoint provides a selective advantage for HIV by allowing virus associated transcription and production of virions, processes which require $\mathrm{T}$ cell cycling.

As discussed above, $\mathrm{Vpr}$ has been shown, in some systems, to induce $\mathrm{T}$ cell apoptosis. In contrast, low level constitutive expression of $\mathrm{Vpr}$ has been shown to inhibit apoptosis by up-regulation of $\mathrm{Bcl}-2$ and down modulation of Bax. ${ }^{90}$ While non-physiologic or ectopic expression of $\mathrm{Vpr}$ may explain these contradictory findings, it is possible that early in infection, low levels of $\mathrm{Vpr}$ protect cells from apoptosis, allowing the cells to increase virus production (Figure 3).

Our own work has shown that $\mathrm{T}$ cells productively infected with HIV-1 IIIB undergo less apoptosis than control uninfected $\mathrm{T}$ cells. ${ }^{91}$ This relative paucity of apoptosis is characteristic of IIIB infection, since a large number of cells infected with the viral clone, HIV-1 NL4-3, are apoptotic. Mapping studies of IIIB and NL4-3 have not revealed the gene product(s) responsible for this marked difference in the death of infected cells, and the mechanism of inhibition of apoptosis by IIIB is not known. Of interest, Bottarel et al. reported that Env from IIIB does not induce CD4 lateral association with Fas, while Env from the apoptosis-inducing strains 451 and MN induces this association. ${ }^{92}$ In related studies, we have shown that productive infection with HIV-1 NL4-3, but not IIIB, inhibits JAK3/STAT5 activation, a signaling pathway required for normal T cell function and survival (Selliah and Finkel, manuscript submitted). We hypothesize that activation of the JAK3/STAT5 pathway protects IIIB infected cells from

\section{Protection of Infected Cells from Apoptosis}

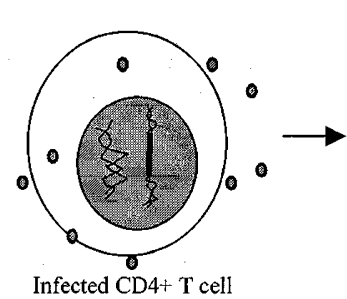

Mechanisms:

- Nef, Vpu, and Env each downregulate CD4 on infected cells. This may help prevent subsequent Env-CD4 interactions and resultant apoptosis.

- Nef downmodulates MHC class I and induces Fas$\mathrm{L}$ expression on infected cells, leading to failure of CTL recognition and clearance of infected cells. Nef inhibits Lck activation which may alter responses to $\mathrm{T}$-cell activation.

- Vpr decreases NFK-B, increases Bcl-2, and inhibits activation-induced cell death.

- Tat increases Bcl-2 and decreases p53.

Figure 3

apoptosis, possibly via activation of the anti-apoptotic targets of JAK3, PI3 kinase and Akt. ${ }^{93}$

Finally, and of most relevance to in vivo infection, we have analyzed apoptosis and HIV-1 RNA in lymph nodes from HIV infected individuals. Lymphoid tissue is a major reservoir of viral infection in HIV disease and a primary site of antigen presentation and lymphocyte activation. Surprisingly, apoptosis is seen predominantly in uninfected bystander cells and not in productively infected cells, ${ }^{43}$ suggesting that infected cells are relatively protected from apoptosis in vivo. While our in vitro work comparing IIIB and NL4-3 did not analyze primary viral isolates, it is intriguing to speculate that these isolates behave like IIIB and inhibit apoptosis in infected cells. Furthermore, we speculate that, as in other viral infections, 'attenuated' HIV is a virus that kills its host cell, having lost or mutated putative anti-apoptotic genes. Viral or cellular targets that inhibit apoptosis, thereby promoting the survival and persistence of HIV-infected cells, may be attractive targets for future therapeutics.

\section{Does current therapy inhibit T cell apoptosis in HIV disease?}

In the early stages of HIV disease, $\mathrm{CD}^{+}$and $\mathrm{CD} 8^{+}$naïve $\mathrm{T}$ cells decline, while CD8 ${ }^{+}$memory $T$ cells expand. ${ }^{94}$ At least one study suggests that naïve $T$ cells are more susceptible to HIV induced bystander cell death. ${ }^{49}$ In the later stages of HIV 
disease, both $\mathrm{CD}^{+}$and $\mathrm{CD}^{+}$memory $\mathrm{T}$ cells decline at similar rates. Within weeks after administration of highly active anti-retroviral therapy (HAART; combination therapy, in general including at least one protease inhibitor and two other anti-retroviral agents), $\mathrm{CD} 4^{+}$and $\mathrm{CD} 8^{+}$memory $\mathrm{T}$ cell populations increase, although significant increases in naïve cells have not been seen. ${ }^{94,95}$ Alteration of the $\mathrm{CD}^{+} \mathrm{T}$ cell repertoire is not immediately corrected by anti-retroviral and/ or immune-based (IL-2) therapy, ${ }^{96}$ although several studies have shown that administration of IL-2 boosts $C D 4^{+} \mathrm{T}$ cell number and function, when used in conjunction with antiretroviral therapy. ${ }^{96-99}$ These studies showed that late expansion of naïve CD4 ${ }^{+} \mathrm{T}$ cells was more pronounced with IL-2 plus HAART than with HAART alone. Furthermore, a recent study showed that while HAART plus IL-2 did not decrease spontaneous apoptosis or AICD, there was a delayed and significant increase in $\mathrm{CD}^{+}$naïve $\mathrm{T}$ cells. ${ }^{99}$ Since IL-2 did not decrease apoptosis, it has been suggested that the increase in naïve T cells may be due to restoration of thymic function or to increased cellular proliferation. ${ }^{99}$ However, only PBL were analyzed in this study, leaving open the possibility that a decrease in apoptosis in lymphoid tissue led to the increase in naïve $T$ cell numbers. In fact, Pandolfi et al. reported that intermittent low dose IL-2 with HAART decreased spontaneous apoptosis and increased the number of $\mathrm{CD}^{+} \mathrm{T}$ cells. ${ }^{100}$ Other studies have shown that anti-retroviral drugs given with IL-2 significantly elevated CD45RO and CD45RA cell numbers and decreased plasma viral load. ${ }^{97,101}$ In addition, CD45RA cells recovered the ability to produce IL-2, IL-4 and IFN-gamma in vitro, suggesting that treated individuals might have an improved immune response. $^{97}$ Collectively, these studies show that the combined use of anti-retroviral drugs and IL-2 may be effective in decreasing viral load, increasing $\mathrm{CD}^{+} \mathrm{T}$ cell numbers, and improving immune system function.

Kovacs et al. reported that intermittent courses of IL-2 (with one anti-retroviral drug) increased CD4 numbers by $50 \%$ in HIV patients with CD4 counts higher than 200 per $\mathrm{mm}^{3}$, but found only minor improvement in patients with low CD4 counts. $^{102}$ IL-2 therapy in patients with low CD4 counts was associated with increased viral replication, but few immunologic improvements. ${ }^{102}$ These data suggest that the use of IL-2 with anti-retroviral drugs may activate resting $T$ cells that harbor replication-competent HIV. A recent report showed that three patients treated with continuous HAART and intermittent IL-2 had significantly fewer resting $\mathrm{CD}^{+} \mathrm{T}$ cells harboring replication-competent HIV RNA. ${ }^{103}$ IL-2 therapy with anti-retroviral drugs not only activates the immune system and, possibly, HIV from latently infected cells, but also, interestingly, decreases the plasma viral load in some patients. ${ }^{104}$ These studies are encouraging, although more patients and long term monitoring are required before definitive conclusions can be drawn.

IL-2 prevents apoptosis of $\mathrm{CD}^{+} \mathrm{T}$ cells from HIV seropositive individuals in vitro, and this is correlated with increased Bcl-2 expression. ${ }^{57}$ Interestingly, IL-15, another $\gamma_{c}$ (the common $\gamma$ chain on IL-2, IL-4, IL-7, IL-9 and IL-15 cytokine receptors) related cytokine, decreased spontaneous apoptosis of T cells from HIV infected individuals. ${ }^{105}$
This inhibition of apoptosis was associated with upregulation of Bcl-2 expression. As discussed above, $\gamma_{c}$ related cytokines may prevent spontaneous apoptosis by activation of the JAK3/STAT5 pathway and by upregulation of survival proteins, such as $\mathrm{Bcl}-2$ and $\mathrm{BCl}_{-x \mathrm{~L}}$. Thus, signaling through $\gamma_{c}$ may protect bystander cells from Env mediated apoptosis and facilitate reconstitution of the $\mathrm{T}$ cell immune system. We hypothesize that $\gamma_{c}$ cytokines, related to but less toxic than IL-2, or selective activation of JAK3, may provide valuable therapeutic tools. In combination with aggressive anti-retroviral therapy, therapies that boost the immune system could significantly delay progression of HIV disease.

\section{References}

1. Daar ES, Moudgil T, Meyer RD and Ho DD (1991) Transient high levels of viremia in patients with primary human immunodeficiency virus type 1 infection. N. Engl. J. Med. 324: $961-964$

2. Clark SJ, Saag MS, Decker WD, Campbell-Hill S, Roberson JL, Veldkamp PJ, Kappes JC, Hahn BH and Shaw GM (1991) High titers of cytopathic virus in plasma of patients with symptomatic primary HIV-1 infection. N. Engl. J. Med. 324: $954-960$

3. Piatak MJ, Saag MS, Yang LC, Clark SJ, Kappes JC, Luk KC, Hahn BH, Shaw GM and Lifson JD (1993) High levels of HIV-1 in plasma during all stages of infection determined by competitive PCR. Science 259: 1749-1754

4. Pantaleo G, Graziosi C and Fauci AS (1993) New concepts in the immunopathogenesis of human immunodeficiency virus infection. N. Engl. J. Med. 328: 327-335

5. Mellors JW, Rinaldo Jr CR, Gupta P, White RM, Todd JA and Kingsley LA (1996) Prognosis in HIV-1 infection predicted by the quantity of virus in plasma [see comments] [published erratum appears in Science 1997 Jan 3;275(5296):14]. Science 272: $1167-1170$

6. Furtado MR, Kingsley LA and Wolinsky SM (1995) Changes in the viral mRNA expression pattern correlate with a rapid rate of CD4+T-cell number decline in human immunodeficiency virus type 1-infected individuals. J. Virol. 69: 20922100

7. Gougeon ML, Lecoeur H, Dulioust A, Enouf MG, Crouvoiser M, Goujard C, Debord T and Montagnier L (1996) Programmed cell death in peripheral lymphocytes from HIV-infected persons: increased susceptibility to apoptosis of CD4 and CD8 T cells correlates with lymphocyte activation and with disease progression. J. Immunol. 156: 3509-3520

8. Cotton MF, Ikle DN, Rapaport EL, Marschner S, Tseng PO, Kurrle R and Finkel TH (1997) Apoptosis of CD4+ and CD8+ T cells isolated immediately ex vivo correlates with disease severity in human immunodeficiency virus type 1 infection. Pediatr. Res. 42: 656-664

9. Hellerstein M, Hanley MB, Cesar D, Siler S, Papageorgopoulos C, Wieder E, Schmidt D, Hoh R, Neese R, Macallan D, Deeks S and McCune JM (1999) Directly measured kinetics of circulating T lymphocytes in normal and HIV-1infected humans [see comments]. Nat. Med. 5: 83-89

10. Fleury S, de Boer RJ, Rizzardi GP, Wolthers KC, Otto SA, Welbon CC, Graziosi C, Knabenhans C, Soudeyns H, Bart PA, Gallant S, Corpataux JM, Gillet M, Meylan P, Schnyder P, Meuwly JY, Spreen W, Glauser MP, Miedema F and Pantaleo G (1998) Limited CD4+ T-cell renewal in early HIV-1 infection: effect of highly active antiretroviral therapy. Nat. Med. 4: 794-801

11. Brunner T, Mogil RJ, LaFace D, Yoo NJ, Mahboubi A, Echeverri F, Martin SJ, Force WR, Lynch DH, Ware CF and Green DR. (1995) Cell-autonomous Fas (CD95)/Fas-ligand interaction mediates activation-induced apoptosis in T-cell hybridomas [see comments]. Nature 373: 441-444

12. Dhein J, WalczakH, BaumlerC, Debatin KMand KrammerPH(1995) Autocrine T-cell suicide mediated by APO-1/(Fas/CD95) [see comments]. Nature 373: $438-441$

13. Ju ST, Panka DJ, Cui H, Ettinger R, el-Khatib M, Sherr DH, Stanger BZ and Marshak-Rothstein A (1995) Fas(CD95)/FasL interactions required for programmed cell death after T-cell activation [see comments]. Nature 373: 444-448 
14. Kaplan D and Sieg S (1998) Role of the Fas/Fas ligand apoptotic pathway in human immunodeficiency virus type 1 disease. J. Virol. 72: 6279-6282

15. Jaworowski A and Crowe SM (1999) Does HIV cause depletion of CD4+ T cells in vivo by the induction of apoptosis? Immunol. Cell Biol. 77: 90-98

16. Silvestris $F$, Cafforio $P$, Frassanito MA, Tucci $M$, Romito $A$, Nagata $S$ and Dammacco $F$ (1996) Overexpression of Fas antigen on T cells in advanced HIV-1 infection: differential ligation constantly induces apoptosis. AIDS 10: $131-141$

17. Aries SP, Schaaf B, Muller C, Dennin RH and Dalhoff K (1995) Fas (CD95) expression on $\mathrm{CD} 4+\mathrm{T}$ cells from HIV-infected patients increases with disease progression. J. Mol. Med. 73: 591-593

18. Katsikis PD, Wunderlich ES, Smith CA and Herzenberg LA (1995) Fas antigen stimulation induces marked apoptosis of $T$ lymphocytes in human immunodeficiency virus-infected individuals. J. Exp. Med. 181: 2029-2036

19. Casella CR, Rapaport EL and Finkel TH (1999) Vpu increases susceptibility of human immunodeficiency virus type 1 -infected cells to fas killing. J. Virol. 73: $92-100$

20. Westendorp MO, Frank R, Ochsenbauer C, Stricker K, Dhein J, Walczak H, Debatin KM and Krammer PH (1995) Sensitization of T cells to CD95-mediated apoptosis by HIV-1 Tat and gp120. Nature 375: 497-500

21. Bartz SR and Emerman M (1999) Human immunodeficiency virus type 1 Tat induces apoptosis and increases sensitivity to apoptotic signals by upregulating FLICE/caspase-8. J. Virol. 73: 1956-1963

22. Zauli G, Gibellini D, Secchiero P, Dutartre H, Olive D, Capitani S and Collette $Y$ (1999) Human immunodeficiency virus type 1 Nef protein sensitizes CD4(+) T lymphoid cells to apoptosis via functional upregulation of the CD95/CD95 ligand pathway. Blood 93: 1000-1010

23. Manna SK and Aggarwal BB (2000) Differential requirement for p56lck in HIVtat versus TNF-induced cellular responses: effects on NF-kappaB, activator protein-1, c-Jun N-terminal kinase, and apoptosis [In Process Citation]. J. Immunol. 164: 5156-5166

24. Jacotot E, Ravagnan L, Loeffler M, Ferri KF, Vieira HL, Zamzami N, Costantini P, Druillennec S, Hoebeke J, Briand JP, Irinopoulou T, Daugas E, Susin SA, Cointe D, Xie ZH, Reed JC, Roques BP and Kroemer G (2000) The HIV-1 viral protein $R$ induces apoptosis via a direct effect on the mitochondrial permeability transition pore. J. Exp. Med. 191: 33-46

25. Macho A, Castedo M, Marchetti P, Aguilar JJ, Decaudin D, Zamzami N, Girard PM, Uriel J and Kroemer G (1995) Mitochondrial dysfunctions in circulating T lymphocytes from human immunodeficiency virus- 1 carriers [see comments]. Blood 86: 2481-2487

26. ReM, Gibellini D, Aschbacher R, Vignoli M, Furlini G, Ramazzotti E, Bertolaso L and La Placa M (1998) High levels of HIV-1 replication show a clear correlation with downmodulation of $\mathrm{Bcl}-2$ protein in peripheral blood lymphocytes of HIV-1seropositive subjects. J. Med. Virol. 56: 66-73

27. Regamey N, Harr T, Battegay M and Erb P (1999) Downregulation of Bcl-2, but not of Bax or Bcl-x, is associated with T lymphocyte apoptosis in HIV infection and restored by antiretroviral therapy or by interleukin 2. AIDS Res. Hum. Retrovir. 15: 803-810

28. Sastry KJ, Marin MC, Nehete PN, McConnell K, el-Naggar AK and McDonnell TJ (1996) Expression of human immunodeficiency virus type I tat results in down-regulation of bcl-2 and induction of apoptosis in hematopoietic cells. Oncogene 13: 487-493

29. Strack PR, Frey MW, Rizzo CJ, Cordova B, George HJ, Meade R, Ho SP, Corman J, Tritch R and Korant BD (1996) Apoptosis mediated by HIV protease is preceded by cleavage of Bcl-2. Proc. Natl. Acad. Sci. U.S.A. 93: 9571-9576

30. Korant BD, Strack P, Frey MW and Rizzo CJ (1998) A cellular anti-apoptosis protein is cleaved by the HIV-1 protease. Adv. Exp. Med. Biol. 436: 27-29

31. Nosaka T, Kawashima T, Misawa K, Ikuta K, Mui AL and Kitamura T (1999) STAT5 as a molecular regulator of proliferation, differentiation and apoptosis in hematopoietic cells. EMBO J. 18: 4754-4765

32. Horita M, Andreu EJ, Benito A, Arbona C, Sanz C, Benet I, Prosper F and Fernandez-Luna JL (2000) Blockade of the Bcr-Abl kinase activity induces apoptosis of chronic myelogenous leukemia cells by suppressing signal transducer and activator of transcription 5-dependent expression of Bcl-xL. J. Exp. Med. 191: 977-984

33. Poon B, Grovit-Ferbas K, StewartSA and Chen ISnY (1998) Cell cycle arrestby $\mathrm{Vpr}$ in HIV-1 virions and insensitivity to antiretroviral agents. Science 281: $266-269$
34. HeJ, Choe S, WalkerR, Di Marzio P, Morgan DO and Landau NR (1995) Human immunodeficiency virus type 1 viral protein $R(V p r)$ arrests cells in the $G 2$ phase of the cell cycle by inhibiting p34cdc2 activity. J. Virol. 69: 6705-6711

35. Re F, Braaten D, Franke EK and Luban J (1995) Human immunodeficiency virus type $1 \mathrm{Vpr}$ arrests the cell cycle in $\mathrm{G} 2$ by inhibiting the activation of p34cdc2-cyclin. B. J. Virol. 69: 6859-6864

36. Hrimech M, Yao XJ, Branton PE and Cohen EA (2000) Human immunodeficiency virus type $1 \mathrm{Vpr}$-mediated G(2) cell cycle arrest: Vpr interferes with cell cycle signaling cascades by interacting with the $B$ subunit of serine/threonine protein phosphatase 2A. EMBO J. 19: 3956-3967

37. Nishizawa M, Kamata M, Katsumata R and Aida Y (2000) A carboxy-terminally truncated form of the human immunodeficiency virus type 1 Vpr protein induces apoptosis via G(1) cell cycle arrest. J. Virol. 74: 6058-6067

38. Stewart SA, Poon B, Song JY and Chen IS (2000) Human immunodeficiency virus type $1 \mathrm{vpr}$ induces apoptosis through caspase activation. J. Virol. 74: 3105-3111

39. Embretson J, Zupancic M, Ribas JL, Burke A, Racz P, Tenner-Racz K and Haase AT (1993) Massive covert infection of helper T lymphocytes and macrophages by HIV during the incubation period of AIDS [see comments]. Nature 362: $359-362$

40. Carbonari M, Cibati M, Pesce AM, Sbarigia D, Grossi P, D'Offizi G, Luzi G and Fiorilli M (1995) Frequency of provirus-bearing CD4+ cells in HIV type 1 infection correlates with extent of in vitro apoptosis of CD8+ but not of CD4+ cells. AIDS Res. Hum. Retrovir. 11: 789-794

41. Bofill M, Gombert W, Borthwick NJ, Akbar AN, McLaughlin JE, Lee CA, Johnson MA, Pinching AJ and Janossy G (1995) Presence of CD3+CD8+Bcl2(low) lymphocytes undergoing apoptosis and activated macrophages in lymph nodes of HIV-1+ patients. Am. J. Pathol. 146: 1542-1555

42. Cotton MF, Cassella C, Rapaport EL, Tseng PO, Marschner S and Finkel TH (1996) Apoptosis in HIV-1 Infection. Behring Inst. Mitt. 220-231

43. Finkel TH, Tudor-Williams G, Banda NK, Cotton MF, Curiel T, Monks C, Baba TW, Ruprecht RM and Kupfer A (1995) Apoptosis occurs predominantly in bystander cells and not in productively infected cells of HIV-and SIV-infected lymph nodes [see comments]. Nat. Med. 1: 129-134

44. Zhang ZQ, Notermans DW, Sedgewick G, Cavert W, Wietgrefe S, Zupancic M, Gebhard K, Henry K, Boies L, Chen Z, Jenkins M, Mills R, McDade H, Goodwin C, Schuwirth CM, Danner SA and Haase AT (1998) Kinetics of CD4+ T cell repopulation of lymphoid tissues after treatment of HIV-1 infection. Proc. Natl. Acad. Sci. U.S.A. 95: 1154-1159

45. Nardelli B, Gonzalez CJ, Schechter M and Valentine FT (1995) CD4+ blood lymphocytes are rapidly killed in vitro by contact with autologous human immunodeficiency virus-infected cells. Proc. Natl. Acad. Sci.U.S.A. 92: 73127316

46. Heinkelein M, Sopper S and Jassoy C (1995) Contact of human immunodeficiency virus type 1 -infected and uninfected $C D 4+T$ lymphocytes is highly cytolytic for both cells. J. Virol. 69: 6925-6931

47. Cicala C, Arthos J, Rubbert A, Selig S, Wildt K, Cohen OJ and Fauci AS (2000) HIV-1 envelope induces activation of caspase-3 and cleavage of focal adhesion kinase in primary human CD4(+) T cells. Proc. Natl. Acad. Sci. U.S.A. 97: $1178-1183$

48. Gratton S, Julius M and Sekaly RP (1998) Ick-independent inhibition of T cell antigen response by the HIV gp120. J. Immunol. 161: 3551-3556

49. Masci AM, Paz FL, Borriello A, Cassano S, Della Pietra V, Stoiber H, Matarese G, Della Ragione F, Zappacosta S and Racioppi L (1999) Effects of human immunodeficiency virus type 1 on CD4 lymphocyte subset activation. Eur. J. Immunol. 29: 1879-1889

50. Biard-Piechaczyk M, Robert-Hebmann V, Richard V, Roland J, Hipskind RA and Devaux C (2000) Caspase-dependent apoptosis of cells expressing the chemokine receptor CXCR4 is induced by cell membrane-associated human immunodeficiency virus type 1 envelope glycoprotein (gp120). Virology 268: 329-344

51. Gervais FG, Thornberry NA, Ruffolo SC, Nicholson DW and Roy S (1998) Caspases cleave focal adhesion kinase during apoptosis to generate a FRNKlike polypeptide. J. Biol. Chem. 273: 17102-17108

52. Wen LP, Fahrni JA, Troie S, Guan JL, Orth Kand Rosen GD (1997) Cleavage of focal adhesion kinase by caspases during apoptosis. J. Biol. Chem. 272: 26056-26061 
53. Katsikis PD, Garcia-Ojeda ME, Torres-Roca JF, Tijoe IM, Smith CA and Herzenberg LA (1997) Interleukin-1 beta converting enzyme-like protease involvement in Fas- induced and activation-induced peripheral blood T cel apoptosis in HIV infection. TNF-related apoptosis-inducing ligand can mediate activation- induced T cell death in HIV infection. J. Exp. Med. 186: 1365-1372

54. Liegler TJ, Yonemoto W, Elbeik T, Vittinghoff E, Buchbinder SP and Greene WC (1998) Diminished spontaneous apoptosis in lymphocytes from human immunodeficiency virus-infected long-term nonprogressors. J. Infect. Dis. 178 669-679

55. Kirsch DG, Doseff A, Chau BN, Lim DS, de Souza-Pinto NC, Hansford R, Kastan MB, Lazebnik YA and Hardwick JM (1999) Caspase-3-dependent cleavage of Bcl-2 promotes release of cytochrome c. J. Biol. Chem. 274: $21155-21161$

56. Hashimoto F, Oyaizu N, Kalyanaraman VS and Pahwa S (1997) Modulation of Bcl-2 protein by CD4 cross-linking: a possible mechanism for lymphocyte apoptosis in human immunodeficiency virus infection and for rescue of apoptosis by interleukin-2. Blood 90: 745-753

57. Adachi Y, Oyaizu N, Than S, McCloskey TW and Pahwa S (1996) IL-2 rescues in vitro lymphocyte apoptosis in patients with HIV infection: correlation with its ability to block culture-induced down- modulation of Bcl-2. J. Immunol. 157: 4184-4193

58. Selliah N and Finkel TH (1998) Cutting edge: JAK3 activation and rescue of T cells from HIV gp120- induced unresponsiveness. J. Immunol. 160: 5697 5701

59. SuzukiK, Nakajima H, Saito Y, Saito T, Leonard WJ and Iwamoto I (2000) Janus kinase 3 (Jak3) is essential for common cytokine receptor gamma chain (gamma(c))-dependent signaling: comparative analysis of gamma(c), Jak3, and gamma(c) and Jak3 double-deficient mice. Int. Immunol. 12: 123-132

60. Thomis DC, Lee W and Berg LJ (1997) T cells from Jak3-deficient mice have intact TCR signaling, but increased apoptosis. J. Immunol. 159: 4708-4719

61. Moriggl R, SexI V, Piekorz R, Topham D and Ihle JN (1999) Stat5 activation is uniquely associated with cytokine signaling in peripheral T cells. Immunity. 11 $225-230$

62. Darnell Jr JE (1997) STATs and gene regulation. Science 277: 1630-1635

63. O'Shea JJ (1997) Jaks, STATs, cytokine signal transduction and immunoregulation: are we there yet? [published erratum appears in Immunity 1997 Sep;7(3):following 444]. Immunity 7: 1-11

64. Pericle F, Pinto LA, Hicks S, Kirken RA, Sconocchia G, Rusnak J, Dolan MJ, Shearer GM and Segal DM (1998) HIV-1 infection induces a selective reduction in STAT5 protein expression. J. Immunol. 160: 28-31

65. Li CJ, Friedman DJ, Wang C, Metelev V and Pardee AB (1995) Induction of apoptosis in uninfected lymphocytes by HIV-1 Tat protein. Science 268: 429 431

66. Ensoli B, Barillari G, Salahuddin SZ, Gallo RC and Wong-Staal F (1990) Tat protein of HIV-1 stimulates growth of cells derived from Kaposi's sarcoma lesions of AIDS patients. Nature 345: 84-86

67. McCloskey TW, Ott M, Tribble E, Khan SA, Teichberg S, Paul MO, Pahwa S, Verdin Eand Chirmule N (1997) Dual role of HIV Tat in regulation of apoptosis in T cells. J. Immunol. 158: 1014-1019

68. Gutheil WG, Subramanyam M, Flentke GR, Sanford DG, Munoz E, Huber BT and Bachovchin WW (1994) Human immunodeficiency virus 1 Tat binds to dipeptidyl aminopeptidase IV (CD26): a possible mechanism for Tat's immunosuppressive activity. Proc. Natl. Acad. Sci. U.S.A. 91: 6594-6598

69. Morimoto C, Lord Cl, Zhang C, Duke-Cohan JS, Letvin NL and Schlossman SF (1994) Role of CD26/dipeptidyl peptidase IV in human immunodeficiency virus type 1 infection and apoptosis. Proc. Natl. Acad. Sci. U.S.A. 91: $9960-9964$

70. Zhang Z, Vuori K, Reed JC and Ruoslahti E (1995) The alpha 5 beta 1 integrin supports survival of cells on fibronectin and up-regulates $\mathrm{Bcl}-2$ expression. Proc. Natl. Acad. Sci. U.S.A. 92: 6161-6165

71. Herbein G, Mahlknecht U, Batliwalla F, Gregersen P, Pappas T, Butler J, O'Brien WA and Verdin E (1998) Apoptosis of CD8+ T cells is mediated by macrophages through interaction of HIV gp120 with chemokine receptor CXCR4 [see comments]. Nature 395: 189-194

72. Krajcsi P and Wold WS (1998) Viral proteins that regulate cellular signalling. J. Gen. Virol. 79: 1323-1335

73. Antoni BA, Sabbatini P, Rabson AB and White E (1995) Inhibition of apoptosis in human immunodeficiency virus-infected cells enhances virus production and facilitates persistent infection. J. Virol. 69: 2384-2392
74. Chinnaiyan AM, Woffendin C, Dixit VM and Nabel GJ (1997) The inhibition of pro-apoptotic ICE-like proteases enhances HIV replication. Nat. Med. 3: 333337

75. Finzi D, Blankson J, Siliciano JD, Margolick JB, Chadwick K, Pierson T, Smith K, Lisziewicz J, Lori F, Flexner C, Quinn TC, Chaisson RE, Rosenberg E, Walker B, Gange S, Gallant J and Siliciano RF (1999) Latent infection of CD4+T cells provides a mechanism for lifelong persistence of HIV-1, even in patients on effective combination therapy [see comments]. Nat. Med. 5: 512-517

76. SalghettiS, Mariani Rand SkowronskiJ (1995) Human immunodeficiency virus type $1 \mathrm{Nef}$ and p561ck protein-tyrosine kinase interact with a common element in CD4 cytoplasmic tail. Proc. Natl. Acad. Sci. U.S.A. 92: 349-353

77. Crise B, Buonocore L and Rose JK (1990) CD4 is retained in the endoplasmic reticulum by the human immunodeficiency virus type $1 \mathrm{glycoprotein} \mathrm{precursor.}$ J. Virol. 64: 5585-5593

78. Willey RL, Maldarelli F, Martin MA and Strebel K (1992) Human immunodeficiency virus type $1 \mathrm{Vpu}$ protein induces rapid degradation of CD4. J. Virol. 66: 7193-7200

79. Margottin F, Bour SP, Durand H, Selig L, Benichou S, Richard V, Thomas D, Strebel K and Benarous R (1998) A novel human WD protein, h-beta TrCp, that interacts with HIV-1 Vpu connects $C D 4$ to the ER degradation pathway through an F-box motif. Mol. Cell. 1: 565-574

80. Greenway A and McPhee D (1997) HIV1 Nef: the Machiavelli of cellular activation. Res. Virol. 148: 58-64

81. Greenway A, Azad A, Mills J and McPhee D (1996) Human immunodeficiency virus type 1 Nef binds directly to Lck and mitogen-activated protein kinase, inhibiting kinase activity. J. Virol. 70: 6701-6708

82. Schaefer TM, Bell I, Fallert BA and Reinhart TA (2000) The T-cell receptor zeta chain contains two homologous domains with which simian immunodeficiency virus Nef interacts and mediates down-modulation. J. Virol. 74: 3273-3283

83. Greenway A, Azad A and McPhee D (1995) Human immunodeficiency virus type 1 Nef protein inhibits activation pathways in peripheral blood mononuclear cells and T-cell lines. J. Virol. 69: 1842-1850

84. Combadiere B, Freedman M, Chen L, Shores EW, Love P and Lenardo MJ (1996) Qualitative and quantitative contributions of the T cell receptor zeta chain to mature T cell apoptosis. J. Exp. Med. 183: 2109-2117

85. Xu XN, Laffert B, Screaton GR, Kraft M, Wolf D, Kolanus W, Mongkolsapay J, McMichael AJ and Baur AS (1999) Induction of Fas ligand expression by HIV involves the interaction of Nef with the T cell receptor zeta chain. J. Exp. Med. 189: $1489-1496$

86. Schwartz O, Marechal V, Le Gall S, Lemonnier F and Heard JM (1996) Endocytosis of major histocompatibility complex class I molecules is induced by the HIV-1 Nef protein. Nat. Med. 2: 338-342

87. Collins KL, Chen BK, Kalams SA, Walker BD and Baltimore D (1998) HIV-1 Nef protein protects infected primary cells against killing by cytotoxic $T$ lymphocytes. Nature 391: 397-401

88. Li CJ, Wang C, Friedman DJ and Pardee AB (1995) Reciprocal modulations between $\mathrm{p} 53$ and Tat of human immunodeficiency virus type 1. Proc. Natl. Acad. Sci. U.S.A. 92: $5461-5464$

89. Clark E, Santiago F, Deng L, Chong S, de La Fuente C, Wang L, Fu P, Stein D, Denny T, Lanka V, Mozafari F, Okamoto T and Kashanchi F (2000) Loss of G(1)/ $S$ checkpoint in human immunodeficiency virus type 1-infected cells is associated with a lack of cyclin-dependent kinase inhibitor p21/Waf1 [In Process Citation]. J. Virol. 74: 5040-5052

90. Conti L, Rainaldi G, Matarrese P, Varano B, Rivabene R, Columba S, Sato A, Belardelli F, Malorni W and Gessani S (1998) The HIV-1 vpr protein acts as a negative regulator of apoptosis in a human lymphoblastoid T cell line: possible implications for the pathogenesis of AIDS. J. Exp. Med. 187: 403-413

91. Rapaport E, Casella CR, Ikle D, Mustafa F, Isaak D and Finkel TH (1998) Mapping of HIV-1 determinants of apoptosis in infected T cells. Virology 252: 407-417

92. Bottarel F, Feito MJ, Bragardo M, Bonissoni S, Buonfiglio D, DeFranco S, Malavasi F, Bensi T, Ramenghi U and Dianzani U (1999) The cell deathinducing ability of glycoprotein 120 from different HIV strains correlates with their ability to induce $\mathrm{CD} 4$ lateral association with $\mathrm{CD} 95$ on $\mathrm{CD} 4+\mathrm{T}$ cells. AIDS Res. Hum. Retrovir. 15: 1255-1263 
93. Sharfe N, Dadi HK and Roifman CM (1995) JAK3 protein tyrosine kinase mediates interleukin-7-induced activation of phosphatidylinositol-3' kinase. Blood 86: 2077-2085

94. Roederer M, Dubs JG, Anderson MT, Raju PA and Herzenberg LA (1995) CD8 naive T cell counts decrease progressively in HIV-infected adults. J. Clin. Invest. 95: 2061-2066

95. Pakker NG, Notermans DW, de Boer RJ, Roos MT, de Wolf F, Hill A, Leonard JM, Danner SA, Miedema F and Schellekens PT (1998) Biphasic kinetics of peripheral blood T cells after triple combination therapy in HIV-1 infection: a composite of redistribution and proliferation [see comments]. Nat. Med. 4: 208-214

96. Connors M, Kovacs JA, KrevatS, Gea-Banacloche JC, Sneller MC, Flanigan M, Metcalf JA, Walker RE, Falloon J, Baseler M, Feuerstein I, Masur H and Lane HC (1997) HIV infection induces changes in CD4+ T-cell phenotype and depletions within the $\mathrm{CD} 4+\mathrm{T}$-cell repertoire that are not immediately restored by antiviral or immune-based therapies [see comments]. Nat. Med. 3: 533-540

97. De Paoli P, Zanussi S, Simonelli C, Bortolin MT, D'Andrea M, Crepaldi C, Talamini R, Comar M, Giacca M and Tirelli U (1997) Effects of subcutaneous interleukin-2 therapy on CD4 subsets and in vitro cytokine production in HIV+ subjects. J. Clin. Invest. 100: 2737-2743

98. Emery S and Lane HC (1997) Immune reconstitution in HIV infection [see comments]. Curr. Opin. Immunol. 9: 568-572

99. Caggiari L, Zanussi S, Bortolin MT, D'Andrea M, Nasti G, Simonelli C, Tirelli U and De Paoli P (2000) Effects of therapy with highly active anti-retroviral therapy (HAART) and IL-2 on CD4+ and CD8+ lymphocyte apoptosis in HIV+ patients. Clin. Exp. Immunol. 120: 101-106

100. Pandolfi F, Pierdominici M, Marziali M, Livia Bernardi M, Antonelli G, Galati V, D'Offizi G and Aiuti F (2000) Low-dose IL-2 reduces lymphocyte apoptosis and increases naive CD 4 cells in HIV-1 patients treated with HAART. Clin. Immunol. 94: $153-159$

101. Simonelli C, Zanussi S, Sandri S, Comar M, Lucenti A, Talamini R, Bortolin MT, Giacca M, De Paoli P and Tirelli U (1999) Concomitant therapy with subcutaneous interleukin-2 and zidovudine plus didanosine in patients with early stage HIV infection. J. Acquir. Immune. Defic. Syndr. Hum. Retrovirol. 20: $20-27$

102. Kovacs JA, Baseler M, Dewar RJ, Vogel S, Davey Jr RT, Falloon J, Polis MA, Walker RE, Stevens R, Salzman NP, Metcalf JA, Masur Hand Lane CH. (1995) Increases in CD4 T lymphocytes with intermittent courses of interleukin-2 in patients with human immunodeficiency virus infection. A preliminary study [see comments]. N. Engl. J. Med. 332: 567-575

103. Chun TW, Engel D, Mizell SB, Hallahan CW, Fischette M, Park S, Davey Jr RT, Dybul M, Kovacs JA, Metcalf JA, Mican JM, Berrey MM, Corey L, Lane HC and Fauci AS (1999) Effect of interleukin-2 on the pool of latently infected, resting $\mathrm{CD} 4+\mathrm{T}$ cells in HIV-1-infected patients receiving highly active anti- retroviral therapy [see comments]. Nat. Med. 5: 651-655

104. Zanussi S, Simonelli C, Bortolin MT, D'Andrea M, Comar M, Tirelli U, Giacca M and De Paoli P (1999) Dynamics of provirus load and lymphocyte subsets after interleukin 2 treatment in HIV-infected patients. AIDS Res. Hum. Retrovir. 15: $97-103$

105. Naora H and Gougeon ML (1999) Interleukin- 15 is a potent survival factor in the prevention of spontaneous but not CD95-induced apoptosis in CD4 and CD8 T lymphocytes of HIV-infected individuals. Correlation with its ability to increase BCL-2 expression. Cell Death Differ. 6: 1002-1011

106. Kolesnitchenko V, WahI LM, Tian H, Sunila I, Tani Y, Hartmann DP, Cossman J, Raffeld M, Orenstein J, Samelson LE and Cohen DI. (1995) Human immunodeficiency virus 1 envelope-initiated G2-phase programmed cell death. Proc. Natl. Acad. Sci. U.S.A. 92: 11889-11893

107. Oyaizu N, McCloskey TW, Than S, Hu R, Kalyanaraman VS and Pahwa S (1994) Cross-linking of CD4 molecules upregulates Fas antigen expression in lymphocytes by inducing interferon-gamma and tumor necrosis factor- alpha secretion. Blood 84: 2622-2631

108. Corbeil J and Richman DD (1995) Productive infection and subsequent interaction of CD4-gp120 at the cellular membrane is required for HIV-induced apoptosis of CD4+ T cells. J. Gen. Virol. 76: 681-690

109. Fermin CD and Garry RF (1992) Membrane alterations linked to early interactions of HIV with the cell surface. Virology 191: 941-946

110. Cohen DI, Tani Y, Tian H, Boone E, Samelson LE and Lane HC (1992) Participation of tyrosine phosphorylation in the cytopathic effect of human immunodeficiency virus-1. Science 256: $542-545$
111. Koga $Y$, Sasaki M, Yoshida H, Wigzell H, Kimura G and Nomoto K (1990) Cytopathic effect determined by the amount of CD4 molecules in human cell lines expressing envelope glycoprotein of HIV. J. Immunol. 144: 94-102

112. Chirmule N, Goonewardena H, Pahwa S, Pasieka R and Kalyanaraman VS (1995) HIV-1 envelope glycoproteins induce activation of activated protein-1 in CD4+ T cells [published erratum appears in J Biol Chem 1995 Dec 1;270(48):29038]. J. Biol. Chem. 270: 19364-19369

113. Popik W and Pitha PM (1996) Binding of human immunodeficiency virus type 1 to CD4 induces association of Lck and Raf- 1 and activates Raf- 1 by a Rasindependent pathway. Mol. Cell. Biol. 16: 6532-6541

114. Levy JA (1993) Pathogenesis of human immunodeficiency virus infection. Microbiol. Rev. 57: 183-289

115. Cheynier R, Henrichwark S, Hadida F, Pelletier E, Oksenhendler E, Autran B and Wain-Hobson S (1994) HIV and T cell expansion in splenic white pulps is accompanied by infiltration of HIV-specific cytotoxic T lymphocytes. Cell 78: $373-387$

116. Brenner BG, Gryllis $C$ and Wainberg MA (1991) Role of antibody-dependent cellular cytotoxicity and lymphokine- activated killer cells in AIDS and related diseases. J. Leukoc. Biol. 50: 628-640

117. Spear GT, Landay AL, Sullivan BL, Dittel B and Lint TF (1990) Activation of complement on the surface of cells infected by human immunodeficiency virus. J. Immunol. 144: 1490-1496

118. Cao J, Park IW, Cooper A and Sodroski J (1996) Molecular determinants of acute single-cell lysis by human immunodeficiency virus type 1. J. Virol. 70: $1340-1354$

119. Glynn JM, McElligott DL and Mosier DE (1996) Apoptosis induced by HIV infection in $\mathrm{H} 9 \mathrm{~T}$ cells is blocked by ICE- family protease inhibition but not by a Fas(CD95) antagonist. J. Immunol. 157: 2754-2758

120. Badley AD, McElhinny JA, Leibson PJ, Lynch DH, Alderson MR and Paya CV (1996) Upregulation of Fas ligand expression by human immunodeficiency virus in human macrophages mediates apoptosis of uninfected Tlymphocytes. J. Virol. 70: 199-206

121. Weinhold KJ, Lyerly HK, Stanley SD, Austin AA, Matthews TJ and Bolognesi DP (1989) HIV-1 GP120-mediated immune suppression and lymphocyte destruction in the absence of viral infection. J. Immunol. 142: 3091-3097

122. Foster S, Beverley $P$ and Aspinall R (1995) gp120-induced programmed cell death in recently activated T cells without subsequent ligation of the T cell receptor. Eur. J. Immunol. 25: 1778-1782

123. Banda NK, Bernier J, Kurahara DK, Kurrle R, Haigwood N, Sekaly RP and Finkel TH (1992) Crosslinking CD4 by human immunodeficiency virus gp120 primes T cells for activation-induced apoptosis. J. Exp. Med. 176: 1099-1106

124. Radrizzani M, Accornero P, Amidei A, Aiello A, Delia D, Kurrle R and Colombo MP (1995) IL-12 inhibits apoptosis induced in a human Th1 clone by gp120/ CD4 cross-linking and CD3/TCR activation or by IL-2 deprivation. Cell. Immunol. 161: 14-21

125. Zinkernagel RM and Hengartner $\mathrm{H}$ (1994) T-cell-mediated immunopathology versus direct cytolysis by virus: implications for HIV and AIDS. Immunol. Today 15: $262-268$

126. Effros RB, Allsopp R, Chiu CP, Hausner MA, Hirji K, Wang L, Harley CB, Villeponteau B, West MD and Giorgi JV (1996) Shortened telomeres in the expanded CD28-CD8+ cell subset in HIV disease implicate replicative senescence in HIV pathogenesis. AIDS 10: F17-F22

127. Wolthers KC, Bea G, Wisman A, Otto SA, de Roda Husman AM, Schaft N, de Wolf F, Goudsmit J, Coutinho RA, van der Zee AG, Meyaard L and Miedema F (1996) T cell telomere length in HIV-1 infection: no evidence for increased CD4+ T cell turnover. Science 274: 1543-1547

128. Estaquier J, Idziorek T, Zou W, Emilie D, Farber CM, Bourez JM and Ameisen JC (1995) Thelper type 1/T helper type 2 cytokines and T cell death: preventive effect of interleukin 12 on activation-induced and CD95 (FAS/APO-1)mediated apoptosis of CD4+ T cells from human immunodeficiency virusinfected persons. J. Exp. Med. 182: 1759-1767

129. Caputo A, Sodroski JG and Haseltine WA (1990) Constitutive expression of HIV-1 tat protein in human Jurkat T cells using a BK virus vector. J. Acquir. Immune Defic. Syndr. 3: 372-379

130. Zauli G, Gibellini D, Milani D, Mazzoni M, Borgatti P, La Placa M and Capitani S (1993) Human immunodeficiency virus type 1 Tat protein protects lymphoid, epithelial, and neuronal cell lines from death by apoptosis. Cancer Res. 53: $4481-4485$ 
131. Gibellini D, Caputo A, Celeghini C, Bassini A, La Placa M, Capitani S and Zaul $\mathrm{G}$ (1995) Tat-expressing Jurkat cells show an increased resistance to different apoptotic stimuli, including acute human immunodeficiency virus-type 1 (HIV1) infection. Br. J. Haematol. 89: 24-33

132. Viscidi RP, MayurK, Lederman HMand Frankel AD (1989) Inhibition of antigeninduced lymphocyte proliferation by Tat protein from HIV-1. Science 246 : 1606- 1608

133. Howcroft TK, Strebel K, Martin MA and Singer DS (1993) Repression of MHC class I gene promoter activity by two-exon Tat of HIV. Science 260: 1320-1322

134. Zauli G, Gibellini D, Caputo A, Bassini A, Negrini M, Monne M, Mazzoni M and Capitani S (1995) The human immunodeficiency virus type-1 Tat protein upregulates Bc1-2 gene expression in Jurkat T-cell lines and primary peripheral blood mononuclear cells. Blood 86: 3823-3834

135. Collette $Y$, Dutartre H, Benziane A, Ramos M, Benarous R, Harris Mand Olive D (1996) Physical and functional interaction of Nef with Lck. HIV-1 Nef-induced Tcell signaling defects. J. Biol. Chem. 271: 6333-6341

136. Saksela K, Cheng G and Baltimore D (1995) Proline-rich (PxxP) motifs in HIV-1 Nef bind to $\mathrm{SH} 3$ domains of a subset of Src kinases and are required for the enhanced growth of Nef+ viruses but not for down-regulation of CD4. EMBO J. 14: $484-491$
137. Jowett JB, Planelles V, Poon B, Shah NP, Chen ML and Chen IS (1995) The human immunodeficiency virus type $1 \mathrm{vpr}$ gene arrests infected T cells in the G2+M phase of the cell cycle. J. Virol. 69: 6304-6313

138. Rogel ME, Wu LI and Emerman M (1995) The human immunodeficiency virus type $1 \mathrm{vpr}$ gene prevents cell proliferation during chronic infection. J. Virol. 69: $882-888$

139. Ayyavoo V, Mahboubi A, Mahalingam S, Ramalingam R, Kudchodkar S, Williams WV, Green DR and Weiner DB (1997) HIV-1 Vpr suppresses immune activation and apoptosis through regulation of nuclear factor kappa $B$ [see comments]. Nat. Med. 3: 1117-1123

140. Luban J, Bossolt KL, Franke EK, Kalpana GV and Goff SP (1993) Human immunodeficiency virus type $1 \mathrm{Gag}$ protein binds to cyclophilins $A$ and $B$. Cell 73: $1067-1078$ 